\title{
Flavonoids from the Fresh Leaves of Kalanchoe tomentosa (Crassulaceae)
}

\author{
Lilis Siti Aisyah ${ }^{1}$, Yenny Febriany Yun ${ }^{1}$, Euis Julaeha ${ }^{1}$, Tati Herlina ${ }^{1}$, Achmad Zainuddin ${ }^{1}$, \\ Wawan Hermawan ${ }^{2}$, Unang Supratman ${ }^{1, *}$ and Hideo Hayashi ${ }^{3}$
}

${ }^{I}$ Department of Chemistry, Faculty of Mathematics and Natural Sciences, Padjadjaran University, Jatinangor 45363 ,
Sumedang, Indonesia; ${ }^{2}$ Department of Biology, Faculty of Mathematics and Natural Sciences, Padjadjaran University,
Jatinangor 45363, Sumedang, Indonesia; ${ }^{2}$ Division of Applied Life Sciences, Graduate School of Life and
Environmental Sciences, Osaka Prefecture University, Gakuen-cho, Sakai, Osaka 599-8531, Japan

Abstract: Flavonoids compounds such as kaempferol (1), kaempferol-3-O- $\beta$-D-glucopyranoside or astragalin (2) and kaempferol-3-O- $\alpha$-L-rhamnoside or afzelin (3) have been isolated from the fresh leaves of Kalanchoe tomentosa (Crassulaceae). The chemical structure of isolated compounds 1-3 were identified by spectroscopic evidences and comparison with those compound previously reported. Compounds 1-3 showed cytotoxic activity against P-388 murine leukimia cells with $\mathrm{IC}_{50}$ values of $51.8,>100$ and $3.32 \mu \mathrm{g} / \mathrm{mL}$, respectively.

Keywords: Crassulaceae, cytotoxic activity, flavonoids, Kalanchoe tomentosa, P-388 murine leukimia cells.

\section{INTRODUCTION}

Kalanchoe tomentosa (Crassulaceae) is a perennial, succulent medicinal herb which grown in high terrain and indigenous to low altitude of Indonesia [1]. The leaves of $K$. tomentosa are used in Indonesian folk medicine for the treatment of fever, infections, rheumatism and skin diseases [2]. The genus of Kalanchoe reported to contain bufadienolides [3-5], triterpenoids [6] and flavonoids [7-9] which possess multiplebiological activities such as blocking human lymphocyte proliferation $[6,10]$, cytotoxic agents [11], insecticidal properties [5, 12] and inhibiting cancer cell growth $[13,14]$. However, information about phytochemical constituents of $K$. tomentosa is unavailable. Our preliminary screening for novel cytotoxic agents from Indonesian Kalanchoe plants, we found that the methanolic extract of $K$. tomentosa exhibited significant cytotoxic effect against P388 murine leukimia cells. In this communication, the isolation and structure identification of flavonoids (1-3) along with their cytotoxic activity against P-388 murine leukimia cells will be described.

\section{EXPERIMENTAL}

\section{General Experimental Procedures}

Ultra-Violet spectra were recorded in methanol on Jasco UV-1575 spectrophotometer. The IR spectra were measured on a Perkin Elmer spectrum-100 FT-IR in KBr. Mass spectra were obtained with a Water, Qtof HR-MS XEV ${ }^{\mathrm{otm}}$ mass spectrometer. NMR spectra were recorded with a JEOL JNM A-500 spectrometer using tetra methyl silane (TMS) as an internal standard. Chromatographic separation was done on

\footnotetext{
*Address correspondence to this author at the Department of Chemistry, Faculty of Mathematics and Natural Sciences, Padjadjaran University, Jl. Raya Bandung-Sumedang Km 21, Jatinangor 45363, Sumedang, West Java, Indonesia; Tel/Fax: +62-22-7794391; E-mail: u supratman@unpad.ac.id
}

silica gel 60 (Merck). PTLC glass plates were precoated with silica gel $\mathrm{GF}_{254}$ (Merck, $0.25 \mathrm{~mm}$ ). TLC plates were precoated with silica gel $\mathrm{GF}_{254}$ (Merck, $0.25 \mathrm{~mm}$ ) and detection was achieved with $10 \% \mathrm{H}_{2} \mathrm{SO}_{4}$ in ethanol followed by heating.

\section{Plant Material}

The fresh leaves of $K$. tomentosa were collected from Lembang Discrict, West Bandung, Indonesia in May, 2011. The plant was identified in Bogoriense Herbarium, Bogor, Indonesia and a voucher specimen (No. B0-129211) was deposited at the herbarium.

\section{Extraction and Isolation}

Fresh grounded leaves $(20 \mathrm{Kg})$ of $K$. tomentosa were extracted with $\mathrm{MeOH}$ at room temperature. The $\mathrm{MeOH}$ extract was evaporated under reduced pressure to yield a dark brown residue $(360 \mathrm{~g})$. The $\mathrm{MeOH}$ extract was dissolved in water and partitioned succesively with $n$ hexane, EtOAc and $n$-butanol. Evaporation of each solvents resulted in the crude extract of $n$-hexane $(30.5 \mathrm{~g})$, EtOAc $(64.5 \mathrm{~g})$ and $n$-butanol $(43.5 \mathrm{~g})$, respectively. The $n$-hexane, ethyl acetate and $n$-butanol extracts exhibited a cytotoxic activity against P-388 murine leukimia cells with $\mathrm{IC}_{50}$ values of $56.5,24.4$ and $45.2 \mu \mathrm{g} / \mathrm{mL}$, respectively. A portion of the EtOAc extract $(50 \mathrm{~g})$ was subjected to vacuum liquid chromatography on silica gel G60 using gradient elution of $n$-hexane-EtOAc-MeOH to afford 15 fractions (A01-A015). Fraction A05 (3.5 g) was further subjected to column chromatography on silica gel (70-230 mesh) using mixture of $n$-hexane-EtOAc $(10: 0-5: 1)$ as eluting solvents to afford 10 fractions (B01-B10). Fraction B04 (230 mg) was subjected to flash column chromatography on silica gel (230400 mesh), eluted with $\mathrm{CHCl}_{3}-\mathrm{MeOH}(9: 1)$, to give 1 (12.4 $\mathrm{mg}$ ). Fraction A06-A07 was combined (4.2 g) and subjected 
to silica gel column chromatography on silica gel (70-230 mesh) using mixture of $n$-hexane-acetone (10:0-1:1) as eluting solvents to give 10 fractions (C01-C10). Fractions C06 (185 g) were subjected to column chromatography on silica gel (230-400 mesh) using mixture of $\mathrm{CHCl}_{3}-\mathrm{MeOH}$ (10:0-1:1) as eluting solvents to afford 6 fractions (D01-D6). Fraction D03 $(73 \mathrm{mg})$ was subjected to preparative TLC on silica gel $\mathrm{GF}_{254}$, eluted with $\mathrm{CHCl}_{3}: \mathrm{MeOH}(9.5: 0.5)$ to give 2 (12.5) and $\mathbf{3}(7.8 \mathrm{mg})$.

\section{Determination of Cytotoxic Activity}

P-388 cells were seeded into 96-well plates at an initial cell density of approximately $3 \times 10^{4}$ cells cm $\mathrm{cm}^{-3}$. After 24 hours of incubation for cell attachment and growth, concentrations of samples were added. The samples first were dissolved in DMSO at the required concentration. Subsequent six concentrations were prepared using PBS (phosphoric buffer solution, $\mathrm{pH}=7.30-7.65$ ). Control wells only DMSO. The assay was stopped after a 48 hours incubation periode by adding MTT reagent [3-(4,5-dimethylthiazol-2yl)-2,5-diphenyl tetra-zolium bromide and the incubation was continued for another 4 hours, in which the MTT-stop solution containing SDS (sodium dodecyl sulphate) was added and another 24 hours incubation was conducted. Optical density was read by using a micro plate reader at $550 \mathrm{~nm}$. $\mathrm{IC}_{50}$ values were taken from the plotted graph of percentage live cells compared to control (\%), receiving only PBS and DMSO, versus the tested concentration of compounds $(\mu \mathrm{g} / \mathrm{mL})$. The $\mathrm{IC}_{50}$ value is the concentration required for $50 \%$ growth inhibition. Each assay and analysis was run in triplicate and averaged.

\section{RESULTS AND DISCUSSION}

Fresh leaves of $K$. tomentosa were grounded and extracted with methanol at room temperature and concentrated. The methanol extract was suspended in water and successively partitioned with $n$-hexane, ethyl acetate and $n$-butanol. The extracts were tested for their cytotoxic activity against P-388 murine leukimia cells and the ethyl acetate extract showed strongest cytotoxic activity. Subsequent phytochemical analysis was therefore focused on the ethyl acetate extract. The ethyl acetate extract was chromatographed over a vacuum liquid cromatography (VLC) column packed with silica gel 60 by gradient elution. The VLC fractions were repeatedly subjected to silica gel column chromatography and preparative TLC on silica gel $\mathrm{GF}_{254}$ to afford three flavonoid compounds 1-3 (Fig. 1).

Compund $\mathbf{1}$ was isolated as a yellowish amorphous. Its UV spectra showed maximum absorption at 272 and $364 \mathrm{~nm}$ in $\mathrm{MeOH}$. Its UV spectra showed bathoromic shifts at 280 and $376 \mathrm{~nm}$ with $\mathrm{NaOH}$ and $\mathrm{AlCl}_{3}$. IR $\lambda_{\max }(\mathrm{KBr}): 3420$, 1690, 1605, 1260, and $720 \mathrm{~cm}^{-1}$. ${ }^{1} \mathrm{H}-\mathrm{NMR}\left(\mathrm{CD}_{3} \mathrm{OD}, 500\right.$ MHz): $\delta 6.28(1 \mathrm{H}, \mathrm{d}, J=1.95 \mathrm{~Hz}, \mathrm{H}-6), 5.95(1 \mathrm{H}, \mathrm{d}, J=1.95$ $\mathrm{Hz}, \mathrm{H}-8), 7.15$ (2H, d, $\left.J=6.90 \mathrm{~Hz}, \mathrm{H}-2^{\prime}, \mathrm{H}^{\prime} 6^{\prime}\right), 7.01$ (2H, d, $\left.J=6.80 \mathrm{~Hz}, \mathrm{H}-3^{\prime}, \mathrm{H}-5^{\prime}\right) .{ }^{13} \mathrm{C}-\mathrm{NMR}\left(\mathrm{CD}_{3} \mathrm{OD}, 125 \mathrm{MHz}\right): \delta$ 157.7 (C-2), 136.6 (C-3), 176.6 (C-4), 162.3 (C-5), 99.2 (C6), 164.9 (C-7), 99.1 (C-8), 104.5 (C-4a), 156.9 (C-8a), 123.3 (C-1'), 128.4 (C-2'), 114.5 (C-3'), 159.4 (C-4'), 114.5 (C-5'), 128.4 (C-6'). HR-TOFMS (positive ion mode) $\mathrm{m} / \mathrm{z}$ 287.0486 [M+H] $]^{+}$, (calcd. for $\left.\mathrm{C}_{15} \mathrm{H}_{10} \mathrm{O}_{6}\right), m / z$ 286.0477).
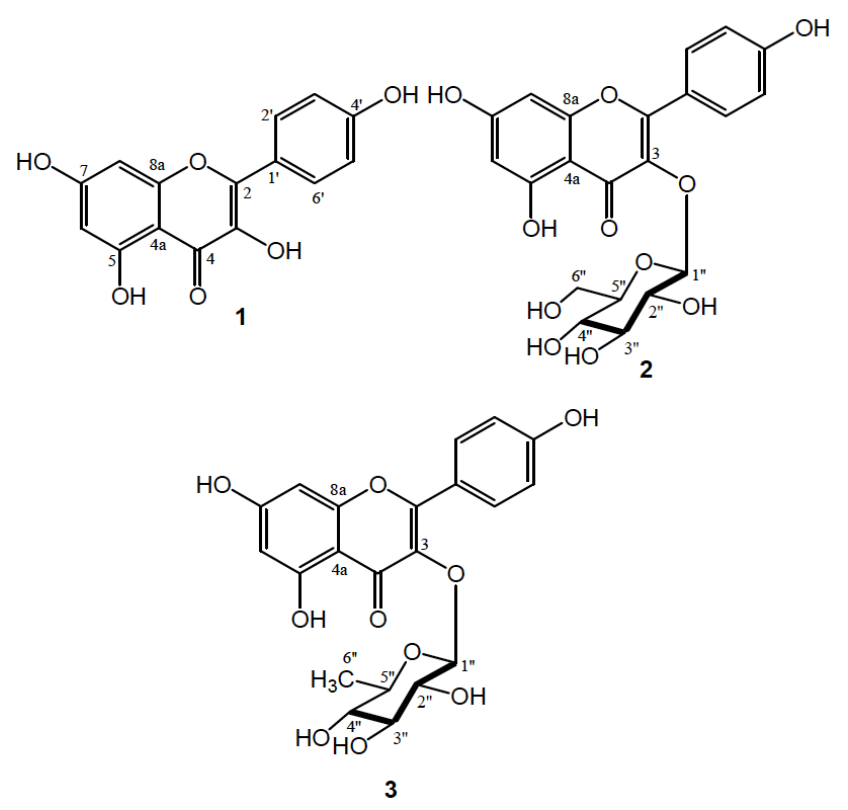

Fig. (1). Structures of isolated compounds 1-3.

Compound 1 has a molecular formula of $\mathrm{C}_{15} \mathrm{H}_{10} \mathrm{O}_{6}$ from its HR-TOFMS spectral data $\left(\mathrm{m} / \mathrm{z} 287.0486[\mathrm{M}+\mathrm{H}]^{+}\right)$and NMR data, thus requiring eleven double bond equivalents. The UV spectrum of 1 showed $\lambda_{\max }$ at 272 and $364 \mathrm{~nm}$ and exhibited a bathochromic shift by added $\mathrm{NaOH}$ and $\mathrm{AlCl}_{3}$ suggested the presence of flavonoid structure having free 4'and 5- hydroxyl groups in $\mathbf{1}$. The IR spectrum of $\mathbf{1}$ showed the absorption band correspond to hydroxyl $\left(3420 \mathrm{~cm}^{-1}\right)$, conjugated carbonyl $\left(1690 \mathrm{~cm}^{-1}\right)$ and conjugated double bond $\left(1605 \mathrm{~cm}^{-1}\right)$. The ${ }^{1} \mathrm{H}-\mathrm{NMR}$ spectrum of 1 showed the presence of two meta-coupled aromatics protons at $\delta 6.28$ and 5.95 corresponds to H-6 and H-8 with coupling constant $1.95 \mathrm{~Hz}$. The ${ }^{1} \mathrm{H}-\mathrm{NMR}$ spectrum of $\mathbf{1}$ also showed the presence of two doublet signals at $\delta 7.15(2 \mathrm{H}, \mathrm{d}, J=6.80 \mathrm{~Hz}$, H-2' and H-6') and $7.01\left(2 \mathrm{H}, \mathrm{d}, J=6.80 \mathrm{~Hz}, \mathrm{H}-3\right.$ ' and $\mathrm{H}-5^{\prime}$ ') corresponds to the four aromatic protons in ring $\mathrm{B}$, characteristics for the 1',4'-disubstituted flavone. A total fifteen carbon signals were observed in the ${ }^{13} \mathrm{C}$-NMR spectrum. These were assigned by DEPT and HMQC experiments to fourteen $\mathrm{sp}^{2}$ carbons and a carbonyl signal at $\delta$ 176.6. The double bond equivalent was accounted for one out of the total eleven double bond equivalents. The remaining ten double bond equivalents were consistent to flavonol structure [14]. A comparison of the NMR data of 1 with those of kaempferol $[14,15]$, revealed that the structures of the two compounds are very similar, therefore, compound $\mathbf{1}$ was identified as kaempferol, which was reported for the first time from $K$. tomentosa.

Compound 2 was isolated as a yellowish solid. UV spectrum $\lambda_{\max }(\mathrm{MeOH}) \mathrm{nm}: 267,350 ; \mathrm{IR} v_{\max }(\mathrm{KBr}) \mathrm{cm}^{-1}$ : 3400, 1730, 1607, 1078. ${ }^{1} \mathrm{H}-\mathrm{NMR}\left(\mathrm{CD}_{3} \mathrm{OD}, 500 \mathrm{MHz}\right): \delta$ $6.18(1 \mathrm{H}, \mathrm{d}, J=1.90 \mathrm{~Hz}, \mathrm{H}-6), 6.36(1 \mathrm{H}, \mathrm{d}, J=1.90 \mathrm{~Hz}, \mathrm{H}-8)$, $7.04(2 \mathrm{H}, \mathrm{d}, J=6.95 \mathrm{~Hz}, \mathrm{H}-2$ ', H-6'), $6.85(2 \mathrm{H}, \mathrm{d}, J=6.95 \mathrm{~Hz}$, H-3', H-5'), 5.20 (1H, d, J=7.5 Hz, H-1' '), $3.79(1 \mathrm{H}, \mathrm{m}, \mathrm{H}-$ 2"'), $3.42(1 \mathrm{H}, \mathrm{m}, \mathrm{H}-3$ '"), $3.42(1 \mathrm{H}, \mathrm{m}, \mathrm{H}-4$ "'), $3.72(1 \mathrm{H}, \mathrm{m}$, $\mathrm{H}-5$ ' '), $3.52\left(1 \mathrm{H}, \mathrm{dd}, J=12.0,4.5 \mathrm{~Hz}, \mathrm{H}_{\mathrm{a}}-6\right.$ '), $3.68(1 \mathrm{H}, \mathrm{dd}$, $J=12.0,2.0 \mathrm{~Hz}, \mathrm{H}_{\mathrm{b}}-6$ ') ${ }^{13} \mathrm{C}-\mathrm{NMR}\left(\mathrm{CD}_{3} \mathrm{OD}, 125 \mathrm{MHz}\right): \delta$ 154.6 (C-2), 135.6 (C-3), 179.4 (C-4), 106.6 (C-4a), 162.6 
(C-5), 100.2 (C-6), 165.8 (C-7), 98.4 (C-8), 159.6 (C-8a), 122.6 (C-1'), 128.4 (C-2'), 116.3 (C-3'), 160.8 (C-4'), 116.3 (C-5'), 128.4 (C-6'), 97.1 (C-1'’), 79.7 (C-2',), 78.1 (C-3'’), 74.3 (C-4'’), 78.4 (C-5'’), 66.6 (C-6'). HR-TOFMS (positive ion mode) $\mathrm{m} / \mathrm{z} 449.3567[\mathrm{M}+\mathrm{H}]^{+}$, (calcd. for $\left.\mathrm{C}_{21} \mathrm{H}_{20} \mathrm{O}_{11}\right), m / z$ 448.3769).

Compound 2 has a molecular formula of $\mathrm{C}_{21} \mathrm{H}_{20} \mathrm{O}_{11}$ from its HR-TOFMS spectral data $\left(m / z 449.3567[\mathrm{M}+\mathrm{H}]^{+}\right)$and NMR data, indicating the presence of twelve double bond equivalents. UV spectrum of 1 displayed $\lambda_{\max }$ at 267 and 350 $\mathrm{nm}$ indicated the presence of a flavonoid skeleton [14]. IR spectrum of 1 indicated the presence of hydroxyl $\left(3400 \mathrm{~cm}^{-1}\right)$, carbonyl $\left(1710 \mathrm{~cm}^{-1}\right)$, conjugated double bond $\left(1607 \mathrm{~cm}^{-1}\right)$ and ether groups $\left(1078 \mathrm{~cm}^{-1}\right) .{ }^{1} \mathrm{H}-\mathrm{NMR}$ spectrum of $\mathbf{2}$ displayed that protons in B ring gave a doublet $(2 \mathrm{H}, \mathrm{d}$, $J=6.95 \mathrm{~Hz})$ at $\delta 7.04$ and 6.85 , suggested the presence $p$ disubstituted benzene ring. Protons in ring A were observed at $\delta 6.18(1 \mathrm{H}, \mathrm{d}, J=1.90 \mathrm{~Hz})$ and $6.36(1 \mathrm{H}, \mathrm{d}, J=1.90 \mathrm{~Hz})$, respectively, suggested the presence of meta-aromatic proton at $\mathrm{H}-8$ and $\mathrm{H}-6$. Based on these observation and comparison of NMR data previously reported [15], indicated that 2 had a kaempferol as a glycone. The ${ }^{1} \mathrm{H}-\mathrm{NMR}$ spectra of $\mathbf{2}$ also showed the presence of an anomeric proton as a doublet at $\delta 5.20$ suggesting a sugar residue was identified as $\beta$ glucopyranose on the basis of coupling constant $\left(J_{1}{ }^{\prime}, 2,,=7.5\right.$ Hz) $[15,16]$. The ${ }^{13} \mathrm{C}-\mathrm{NMR}$ spectrum showed 21 carbon signals, which were classified by their chemical shifts and the DEPT spectra as one oxygenated $\mathrm{sp}^{3}$ methylene, four oxygenated $\mathrm{sp}^{3}$ methines, one anomeric carbon, six $\mathrm{sp}^{2}$ methines, eight $\mathrm{sp}^{2}$ quartenary carbon and one carbonyl. The double bond equivalen was accounted for eight out of the total twelve double bond equivalents. The remaining four double bond equivalens were consistent with the flavone skeleton with a $\beta$-glucose residue [15]. Based on the above evidences and biogenetic point of view occurance the flavonoid structure in Kalanchoe genus, suggested that compound 2 having flavonoid structure [14-16] consists of kaempferol as an aglycone moiety and $\beta$-D-glucoside as a sugar residue. The position of the $\beta$-D-glucosyl moiety in $\mathbf{2}$ was identified at $\mathrm{C}-3$ position on the basis of COSY and HMBC correlations as shown in Fig. (2). Consequently, structure 2 was identified as kaempferol-3-O- $\beta$-D-glucoside or known as astragalin consistent to the reported literature values $[16,17]$, which was reported for the first time from $K$. tomentosa.

Compund $\mathbf{3}$ was isolated as a yellow solid. Its UV spectra showed maximum absorption at 276 and $370 \mathrm{~nm}$ in $\mathrm{MeOH}$. IR $v_{\max }(\mathrm{KBr}): 3360,1670,1607,1508,1452$, 1024 and $820 \mathrm{~cm}^{-1}$. ${ }^{1} \mathrm{H}-\mathrm{NMR}$ ( $\left.\mathrm{CD}_{3} \mathrm{OD}, 500 \mathrm{MHz}\right)$ : $\delta 12.55(1 \mathrm{H}, \mathrm{s}, 5-\mathrm{OH}), 7.20\left(2 \mathrm{H}, \mathrm{d}, J=7.20 \mathrm{~Hz}, \mathrm{H}-\mathrm{2}^{\prime}, \mathrm{H}-6^{\prime}\right)$, 6.90 (2H, d, J=7.20 Hz, H-3', H-5'), 6.10 (1H, d, J=2.0 Hz, $\mathrm{H}-8), 5.95$ (1H, d, $J=2.0 \mathrm{~Hz}, \mathrm{H}-6), 5.49$ (1H, d, $J=1.9 \mathrm{~Hz}, \mathrm{H}-$ 1 ') 3.80 (1H, dd, $J=8.0,7.1 \mathrm{~Hz}, \mathrm{H}-2$ ''), 3.45 (1H, dd, $J=10.0,4.30 \mathrm{~Hz}, \mathrm{H}-3$ ' '), 3.42 (1H, t, $J=10.0 \mathrm{~Hz}, \mathrm{H}-4$ ' '), 3.74 $(1 \mathrm{H}, \mathrm{dd}, J=10.0,6.1 \mathrm{~Hz}, \mathrm{H}-5$ ' '), $0.94(3 \mathrm{H}, \mathrm{d}, J=6.0 \mathrm{~Hz}, \mathrm{H}-$ 6"'); ${ }^{13} \mathrm{C}-\mathrm{NMR}\left(\mathrm{CD}_{3} \mathrm{OD}, 125 \mathrm{MHz}\right): \delta 153.6$ (C-2), 134.6 (C-3), 179.7 (C-4), 104.5 (C-4a), 163.3 (C-5), 98.6 (C-6), 165.5 (C-7), 99.4 (C-8), 155.0 (C-8a), 124.0 (C-1'), 128.4 (C-2'), 114.6 (C-3'), 158.0 (C-4'), 114.6 (C-3'), 128.4 (C2'), 97.0 (C-1'’), 74.8 (C-2'’), 77.5 (C-3'’), 78.6 (C-4'’),
75.6 (C-5' '), 20.8 (C-6'), HR-TOFMS (positive ion mode) $m / z 433.1104[\mathrm{M}+\mathrm{H}]^{+}$, (calcd. for $\left.\mathrm{C}_{21} \mathrm{H}_{20} \mathrm{O}_{10}\right), m / z$ 432.1056).

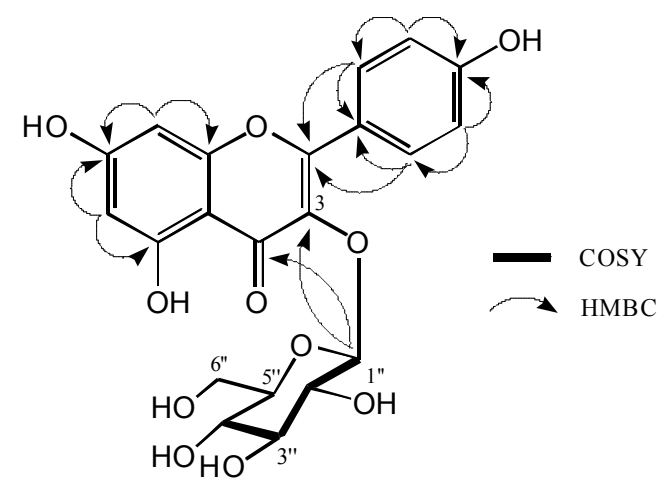

Fig. (2). Selected COSY and HMBC Correlations of 2.

Compound 3 has a molecular formula of $\mathrm{C}_{21} \mathrm{H}_{20} \mathrm{O}_{10}$ from its HR-TOFMS spectral data $\left(\mathrm{m} / \mathrm{z} 433.1102[\mathrm{M}+\mathrm{H}]^{+}\right)$and NMR data, thus requiring twelve degrees of unsaturation. The UV spectrum of 3 showed $\lambda_{\max }$ at 276 and $370 \mathrm{~nm}$ indicated a flavonoid structure $[14,15]$. The IR spectrum of $\mathbf{3}$ showed the presence of hydroxyl $\left(3360 \mathrm{~cm}^{-1}\right)$, conjugated carbonyl $\left(1670 \mathrm{~cm}^{-1}\right)$, conjugated double bond $\left(1607 \mathrm{~cm}^{-1}\right)$ and ether group $\left(1024 \mathrm{~cm}^{-1}\right) .{ }^{1} \mathrm{H}-$ and ${ }^{13} \mathrm{C}$ NMR signals of 3 were similar to those of $\mathbf{2}$, the main differences are the presence of a secondary methyl group at as a doublet at $\delta$ $0.94(3 \mathrm{H}, \mathrm{d}, J=5.7 \mathrm{~Hz})$ and absence of oxymethylene group at C-5 position of the sugar unit, suggested that compound 3 is consist a flavonoid skeleton of kaempferol as an aglycone moiety and rhamnoside as a sugar unit. The anomeric proton had a coupling constant of $1.9 \mathrm{~Hz}$, conforming the $\alpha$ orientation of L-rhamnosyl moiety. Based on the above spectral data, structure 3 was identified as kaempferol-3-O$\alpha$-L-rhamnoside consistent with previously reported $[14,18]$, which was reported for the first time from $K$. tomentosa.

The cytotoxic effects of the three isolated compounds 1-3 against the P-388 murine leukimia cells were conducted according to the method described in previous paper $[19,20]$ and were used an artonin $\mathrm{E}\left(\mathrm{IC}_{50} 0.3 \mu \mathrm{g} / \mathrm{mL}\right)$ as a positive control [21]. Compounds 1-3 showed cytotoxicity against P388 murine leukimia cells with $\mathrm{IC}_{50}$ values of $51.8,>100$ and $3.32 \mu \mathrm{g} / \mathrm{mL}$, respectively, suggested that the presence of rhamnoside sugar unit in flavonoid structure can increase cytotoxic activity whereas the presence of glucoside unit can decrease cytotoxic activity.

\section{CONCLUSION}

The ethyl acetate extract of $K$. tomentosa fresh leaves showed the presence of flavonoid structure, kaempferol (1), kaempferol-3-O- $\beta$-D-glucoside or astragalin (2) and kaempferol-3-O- $\alpha$-L-rhamnoside or afzelin (3). The presence of rhamnoside sugar unit in flavonoid structure can increase the cytotoxic activity against P-388 murine leukimia cells.

\section{CONFLICT OF INTEREST}

The authors confirm that this article content has no conflict of interest. 


\section{ACKNOWLEDGEMENTS}

This investigation was financially supported by Directorate General of Higher Education, Ministry of Education and Culture, Indonesia (PUPT Scheme, 20132014, by EJ). We thank Mr. Achmad Darmawan and Mrs. Sofa Fajriah in the Research Center for Chemistry, Indonesian Science Institute, for NMR measurements. We are grateful to Mr. Uji Pratomo at Center Laboratory of Padjadjaran University for HR-TOFMS measurements.

\section{REFERENCES}

[1] Heyne, K. The Useful Indonesian Plants, Research and Development Agency, Ministry of Forestry, Jakarta, Indonesia, 1987, pp. 845-846.

[2] Hutapea, J.R. Inventory of Indonesian Medicinal Plants. Research and Development Agency, Ministry of Health, Jakarta, Indonesia, 1994, pp. 117-118.

[3] Capon, R.J., MacLeod, J.K., Oelrichs, P.B. Bryotoxin B and C, toxic bufadienolide orthoacetates from the flowers of Bryophyllum tubiflorum (Crassulaceae). Aust. J. Chem., 1986, 39, 1711-1715.

[4] Yamagishi, T., Haruna, M., Yan, X.Z., Chang, J.J., and Lee, K.H. Antitumor agents, 110, Bryophyllin B, a novel potent cytotoxic bufadienolide from Bryophyllum pinnatum. J. Nat. Prod., 1989, 52, 1071-1079.

[5] Supratman, U., Fujita, T., Akiyama, K., Hayashi, H. New insecticidal bufadienolide, bryophyllin $\mathrm{C}$, from Kalanchoe pinnata. Biosci. Biotechnol. Biochem., 2000, 64, 1309-1311.

[6] Gaind, K.'N., Singla, A.'K., Boar, R.B., Copsey, D.B. Triterpenoids and sterols of Kalanchoe spathulata. Phytochemistry, 1976, 15, 1999-2000.

[7] Costa, S. S., Jossang, A., Boda, R.B. 4"'"-Acetylsagittatin A, a Kaempferol Triglycoside from Kalanchoe streptantha. J. Nat. Prod., 1996, 59, 327-329.

[8] Liu, K. C. S., Yang, S. L., Robert, M. F., Phlipson, J. D. Flavonol glycosides with acetyl substitution from Kalanchoe gracilis. Phytochemistry, 1989, 28, 2813-2818.

[9] Liu, K. C. S., Yang, S. L., Robert, M. F., Phlipson, J. D. Eupafolin rhamnosides from Kalanchoe gracilis. J. Nat. Prod. 1989, 52, 970974.
[10] Almeida, A. P., Da Silva, S. A. G., Souza, M. L. M., Lima, L. M. T., Rossi-Bergmann, B., Goncalves de Moraes, V. L., Costa, S. S. Isolation and chemical analysis of a fatty acid fraction of Kalanchoe pinnata with a potent lymphocyte suppressive activity. Planta Med., 2000, 66, 134-137.

[11] Wu, P. L., Hsu, Y. L., Wu, T. S., Bastow, K. F., Lee, K. H. Kalnchosides A-C, New cytotoxic bufadienolides from the aerial parts of Kalanchoe gracilis. Org. Lett., 2006, 8(23), 5207-5210.

[12] Supratman, U., Fujita, T., Akiyama, K., Hayashi, H. Insecticidal compounds from Kalanchoe daigremontiana $\mathrm{x}$ tubiflora. Phytochemistry, 2001, 58, 311-314.

[13] Supratman, U., Fujita, T., Akiyama, K., Hayashi., Murakami, A., Sakai, H., Koshimizu, K., Ohigashi, H. Anti-tumor promoting activity of bufadienolides from Kalanchoe pinnata and $K$. daigremontiana x tubiflora. Biosci. Biotechnol. Biochem., 2001 65, 947-949.

[14] Toker, G., Memisoglu, M., Yesilada, E., Aslan, M. Main flavonoids of Tilia argentea DESF ex DC leaves. Turk. J. Chem., 2004, 28, 745-749.

[15] Nakano, K., Takatani, M., Tomimatsu, T. Four kaemferol glycosides from leaves of Cinnamomum sieboldii. Phytochemistry, 1983, 22(12), 2831-2833.

[16] Furusawa, M., Tanaka, T., Ito, T., Nakaya, K., Iliya, I., Ohyama, M., Iinuma, M., Murata, H., Inatomi, Y., Inada, A., Nakanishi, T. Matsushita, S., Kubota, Y., Sawa, R., Takahashi, Y. Flavonol glycosides in leaves of two Diospyros species. Chem. Pharm. Bull., 2005, 53(5), 591-593.

[17] Kuruuzum-uz, A., Guvenalp, Z., Kazaz, C., Demirer, L. O. Phenolic compounds from the roots of Anchusa azurea var azurea. Turk. J. Pharm. Sci., 2013, 10(2), 177-184.

[18] Chaturvedula, V.S.P., Prakash, I. Kaempferol glycosides from Siraitia grosvenorii. J. Chem. Pharm. Res., 2011, 3(6), 799-804.

[19] Sahidin, Hakim, E.H., Juliawaty, L.D., Syah, Y.M., Din, L.B., Ghisalberti, E.L., Latip, J., Said, I.M., Achmad, S.A. Cytotoxic properties of oligostilbenoids from the tree bark of Hopea dryobalanoides. Z Naturforsch., 2005, 60c, 723-727.

[20] Harneti, D., Tjokronegoro, R., Safari, A., Supratman, U., Loong, X. M., Mukhtar, M. R. Mohamad, K., Awang, K., Hayashi., H. Cytotoxic triterpenoids from the bark of Aglaia smithii. Phytochem. Lett., 2012, 5, 496-499.

[21] Hakim, E. H., Achmad, S. A., Juliawaty, L. D., Makmur, L., Syah, Y. M., Aimi, A., Kitajima, M., Takayama, H., Ghisalberti, E. L. Prenylated flavonoids and related compounds of the Indonesian Artocarpus (Moraceae). J. Nat. Med., 2007, 61(2), 229-236.

Received: February 28, 2015

Revised: August 11, 2015

Accepted: September 16, 2015

(C) Aisyah et al.; Licensee Bentham Open.

This is an open access article licensed under the terms of the (https://creativecommons.org/licenses/by/4.0/legalcode), which permits unrestricted, noncommercial use, distribution and reproduction in any medium, provided the work is properly cited. 